\title{
Domestic vs. International Explanations of Recent U.S. Manufacturing Developments
}

\author{
John A. Tatom
}

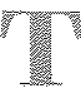
markets rose sharply from 1980 to 1985 , prompting the emergence of a hypothesis that links the growth of the nation's manufacturing sector and developments in the foreign exchange market. This hypothesis holds that the appreciation of the dollar has raised the cost of U.S. goods, especially manufactured goods, to uncompetitive levels in the world market.' As a result, manufacturing output in the United States has stagnated, especially relative to manufacturing in competing nations.

This intemational explanation suffers from a common analytical problem in economic analysis: the failure to distinguish between supply and demand changes. In the simplest analysis, for example, an increase in the supply of a product, given prices, is expected to reduce the price of the product so that purchases's will be induced to buy more. Thus, the price falls, just as it would if demand fell at initially

John A. Tatom is an assistant vice president at the Federal Reserve Bank of St. Louis. Michael L. Durbin provided research assistance.

'The international explanation applies to all goods and services, though manufacturing is typically singled out because such goods constitute a relatively large share of U.S. exports and imports. Since 1980 , the international hypothesis has become increasingly popular, and in recent years it has been presented in virtually every national magazine and newspaper. Lawrence (1984) is an advocate of this view. This is somewhat surprising, since he also emphasizes the importance of the cyclical view of manufaciuring developments in the 1970 s and links the decline in the dollar in the 70 s to the relative weakness of U.S. manufacturing productivity. Solomon (1985) and Fieleke (1985) also discuss the intemational view and provide evidence that is at odds with it. unchanged prices. The principal difference is this: when a cost of productivity shift initiates the price reduction, the industry expands; when a demand shift initiates the price reduction, the industry shrinks.

The international hypothesis focuses on the effects of an exchange rate change only on the demand for goods. But if the supply of output grows in one country because of an increase in its resources or productivity, the prices of affected products will fall and the domestic industry will expand. A rise in the exchange rate then will be required to restore the equality of product prices across countries. Thus, it is not necessarily cofrect to expect that an appreciation of the dollar reduces the output and employment of domestic exporters and import competing firms.

What's more, a decline in U.S. manufacturing output can occur as much due to a shift in domestic demand as foreign demand. This point is part of the domestic view of U.S. manufacturing output fluctuations, which emphasizes the sensitivity of manufacturing to cyclical movements in U.S. real income and the importance of supply changes in altering the exchange rate."

\footnotetext{
2Norton (1986) agrees with Lawrence that, in the 1970 s, adverse movements in U.S. manufacturing output and employment were the result of domestic "cyclical effects;" while, in this decade, they have been the result of short-run trade effects associated with macroeconomic policies that presumably raised the value of the dollar. But Norton also notes two influential studies that dismiss the "overvalued dollar" view and argues that such a view is too simple and ignores the fact that a "depreciating dollar is a sign of decline" ( $p$. 16).
} 


\section{Chart 1 \\ U.S. Manufacturing Output and Employment}

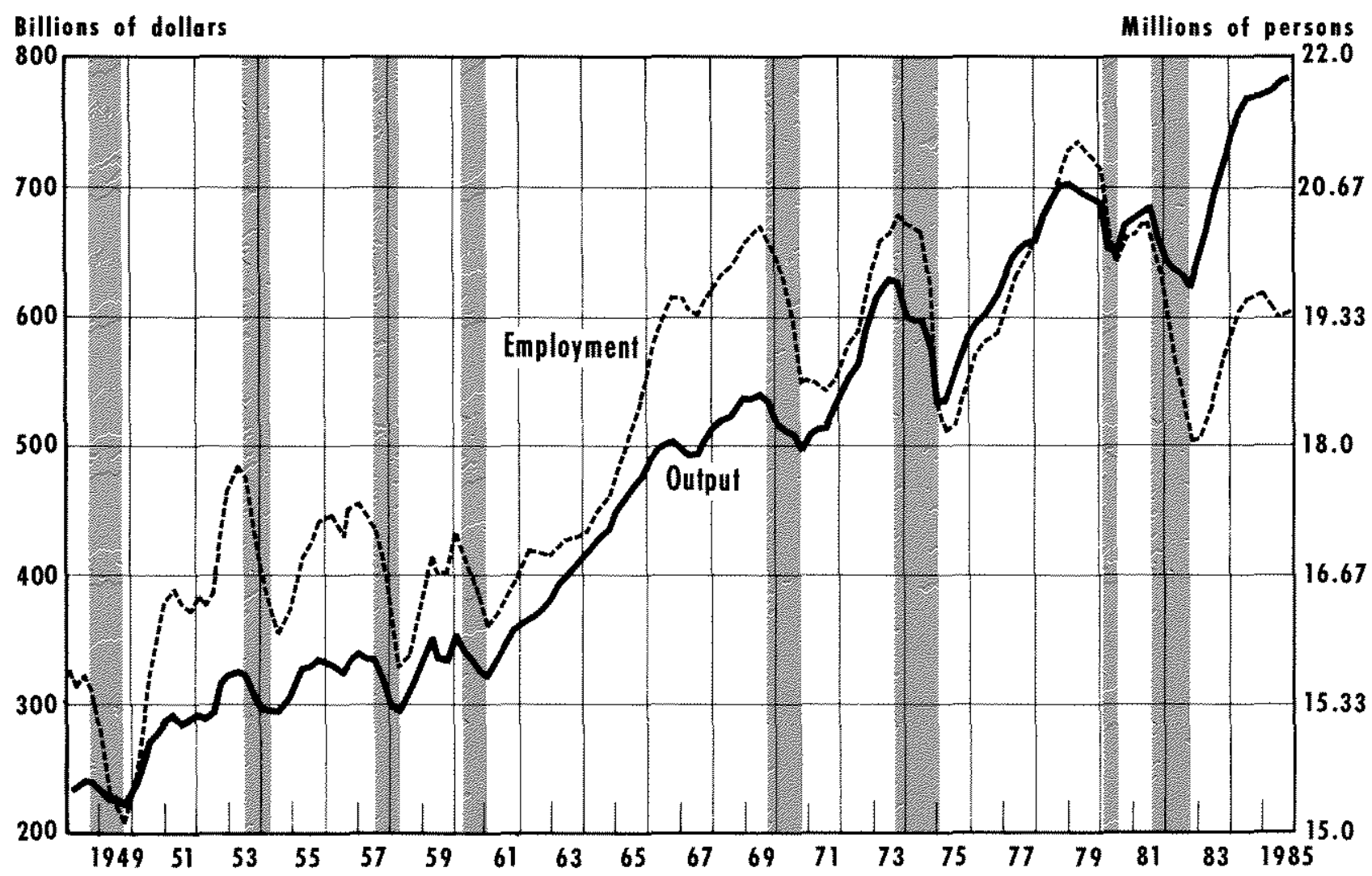

This article suggests that manufacturing output in the Unted States has not been systematically weakened during the period of dollar appreciation. Instead, it has been stronger than gans in domestic income alone can explain. On the demand side, domestic cyclical movements in real income provide the best explanation for manufacturing growth in the first half of this decade because they account for both the slow and the boom periods that, on net, have left manufacturing output above its $1948-80$ average share of the nation's output. The article also suggests that economic policy has had supply-side effects on U.S. manufacturing that not only improved the intemational competitive position of the United Slates, but also raised the value of the dollar.

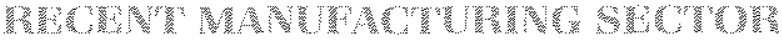

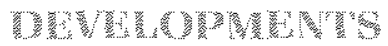

Manulacturing output in the United States has been volatile since 1980. Chamt 1 shows output and employment in the manufacturing sector. Output is gross domestic product originating in manufachuring 1982 prices on real value added in that sector from 1947 to 1979 , manufacturing output grew at a 3.6 percent rate, but employment rose much more slowly, averaging a 0.9 perent rate of growth over the period, Since then, there have been periods of declining output (1/1980 to III/1980 and II//1981 to W/T982), relatively slow growth III/1984 to IV/1985\} and rapid advance $\{\mathrm{IV} / 1982$ to III 1984. In the recent period of slow growth. manuacturing output expanded at only a 1.5 percent rate, while employment fell by 131,600 persons, a 0.5 percent rate of dedine.

The periods of declining, relatively slow, and fast growth of manufacturing in the 1980 s closely follow cyclical movements in domestic real income. As chat 2 shows, during the shaded recession periods, real income (GNP) declines, but manufacturing ontpat 
Chart 2

\section{Growth Rates of Manufacturing Output and Real GNP}

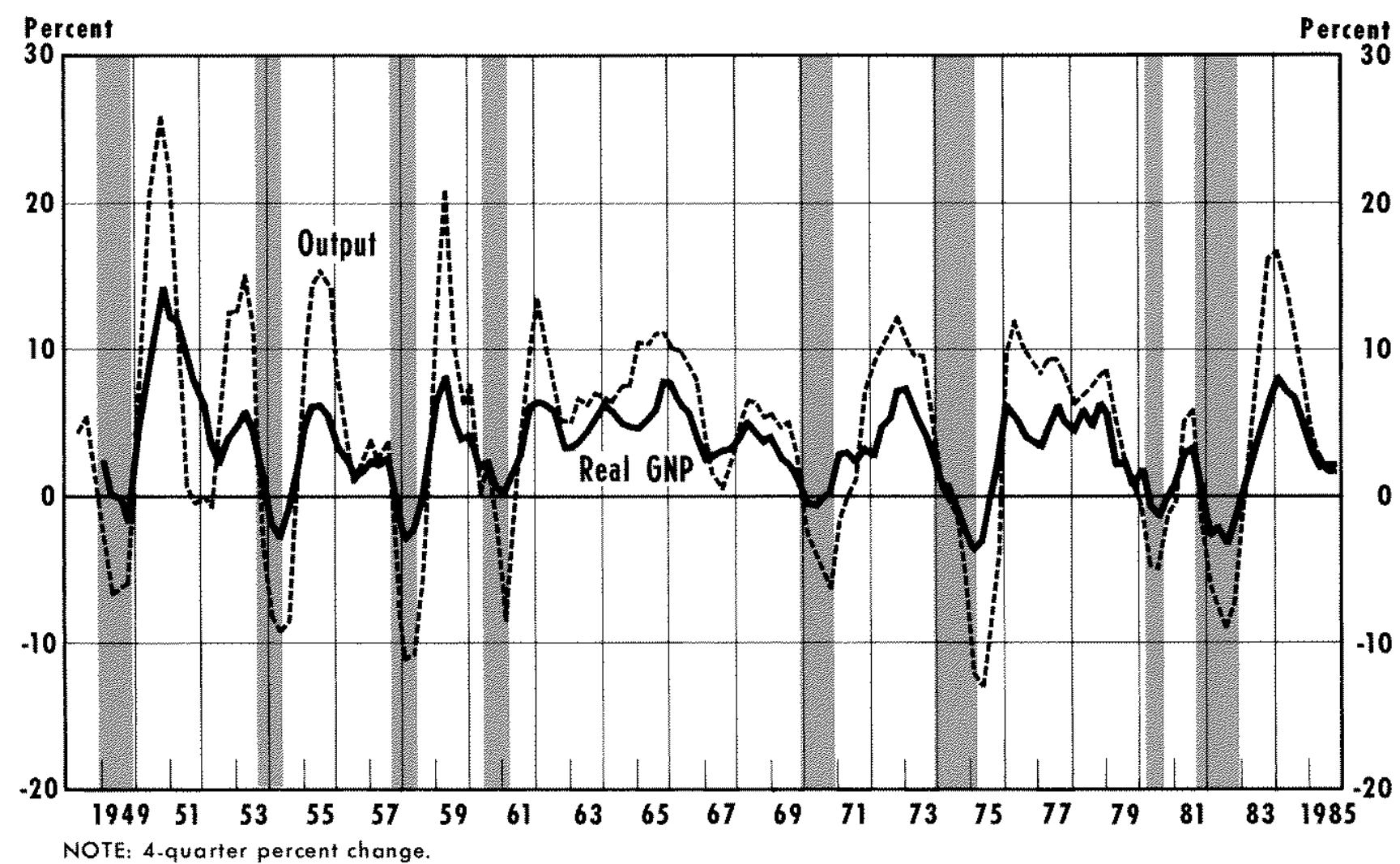

falls even more; during periods when real GNP grows relatively rapidly, manufacturing output growth tends to be stronger.

There are two principal explanations for the cyclical sensitivity of manufacturing output. The first, called the "pemanent income" hypothesis, emplasizes that when real income is temporarily depressed, purchases of duable manufactured goods tend to be postponed; when real incone is temporarily higher, most of the income gain is saved for future consumption, including saving in the form of duable goods acquisition." The second explanation emplasizes the responsiveness of supply to price changes. Variations in demand, including those due to cyclical real income changes, have little effect on the prices of goods whose supply is very responsive to price. The supply

3See Milton Friedman (1957). The pioneering application of this concept to the demand for durable goods is developed by Harberger (1960) and the studies therein. of other goods is relatively less responsive to price variation, and these goods show greater price variability when real income fluctuates. The manufacturing sector is usually characterized as having relatively less flexible prices so that variations in demand affect output relatively more, and price relatively less, than in other sectors of the economy.

The experience of the 1980 s appears to be consistent with the previous cyclical experience. The recent intervals of slow or negative growth appear to be due to cyclical movements in real income. But the cyclical volatility in chart 1 may be obseuring a general tendency for manufacturing output growth to have been depressed by the rise in the value of the dollar.

${ }^{4}$ Okun (1981) develops aggregate theories of price adjustment and cyclical behavior based on the distinction between what he called "flex-price" and "fixed-price" industries. The elasticity of supply in a competitive industry plays only a minor rote in this work. Other factors. such as the objectives of firms and degrees of competitiveness, play more important roles in Okun's analysis. 


\section{Chant 3}

\section{The Nominal Trade-Weighted Exchange Rate}

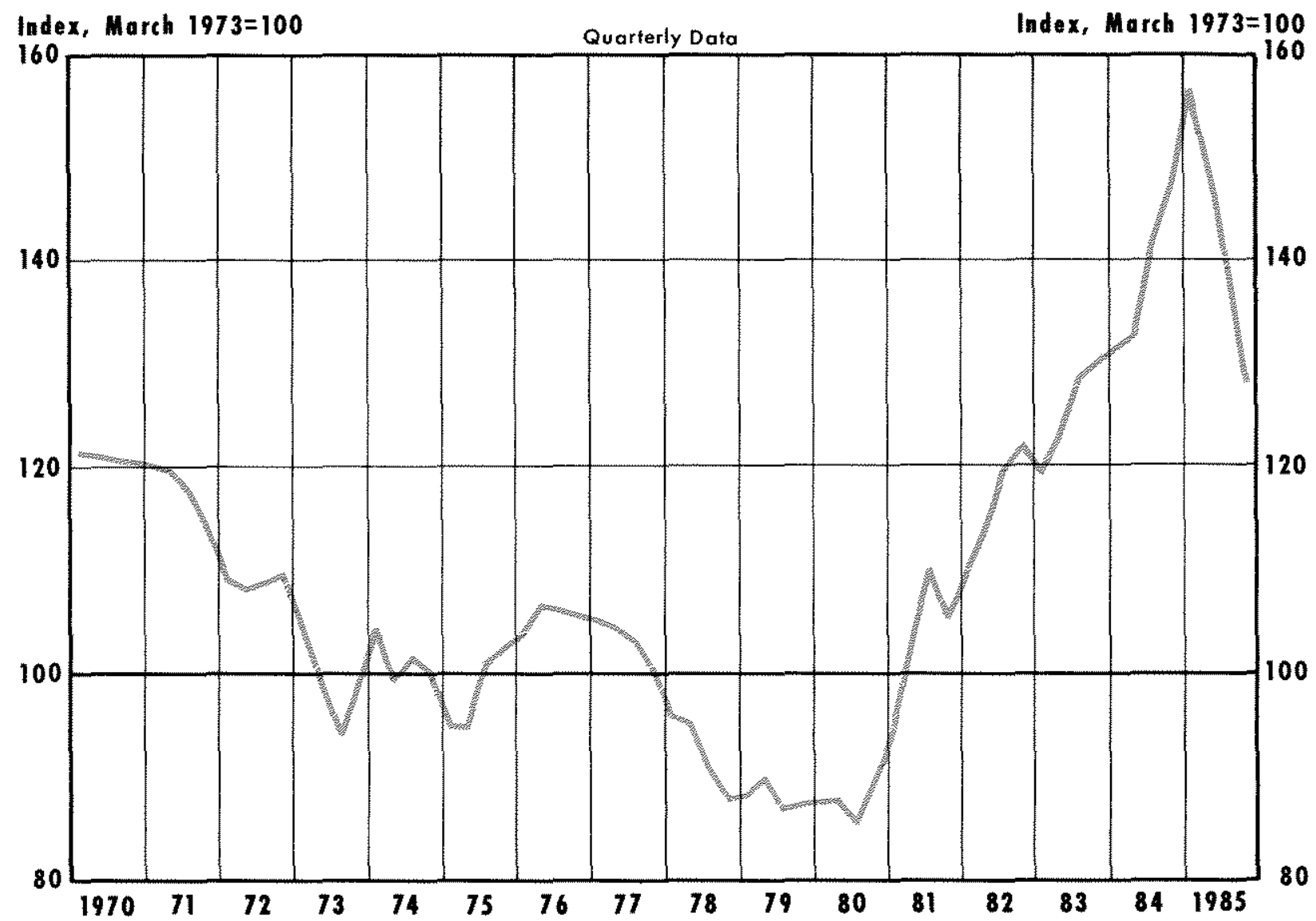

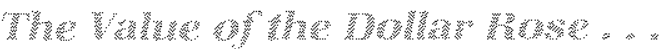

An appreciation in the value of the dollar is frequently blamed for recent weakness in the growth of U.S. manufacturing output. When the price of the dollar in units of foreign currency rises, the prices of U.S. goods measured in foreign currencies also increase, given the dollar prices of those goods. On the other hand, foreign currencies become cheaper, making the dollar prices of foreign goods lower. As a result. both foreigners and domestic residents buy fewer U.S. goods and more foreign goods. From the U.S. point of view, exports fall, while imports of foreign goods increase.

As chart 3 shows, the marked appreciation in the value of the dollar began in late 1980 and continued until the first quarter of 1985 . Over the period, the exchange rate rose fairly steadily at a $\mathbf{1 4 . 4}$ pereent annual rate. Over the remaining three quarters of 1985 , the value of the dollar fell at a 26 percent rate, reaching an end-of-year value near its early 1983 level. The earlier rise in the dollar's value has been held responsible for the dismal performance in manufacturing, and the same view suggests that the recent depreciation will lead to renewed strength.

In principle, the appropriate measure of the exchange value of the dollar is the "real" exchange rate, which takes into account changes in U.S. and foreign prices. For example, the real exchange rate rose at a 13.2 percent rate over the period $11 / 1980$ to $/ / 1985$. The difference between the growth rates of the nominal and real exchange rate reflects an average annual rate of price increase abroad that was about 1.1 percent per year higher than in the United States. For empirical purposes, there is little difference between the two series. From $1 / 1970$ to $11 / 1985$, a regression of the growth in the real exchange rate on a constant and the growth rate of the nominal exchange rate, with significant autocorrelation correction, accounts for 97 percent of the variation in the real exchange rate. Of course, the coefficient on the nominal exchange rate is not significantly different from one. 


\section{Chart 4}

\section{U.S. Manufacturing Output as a Percent of Real GNP}

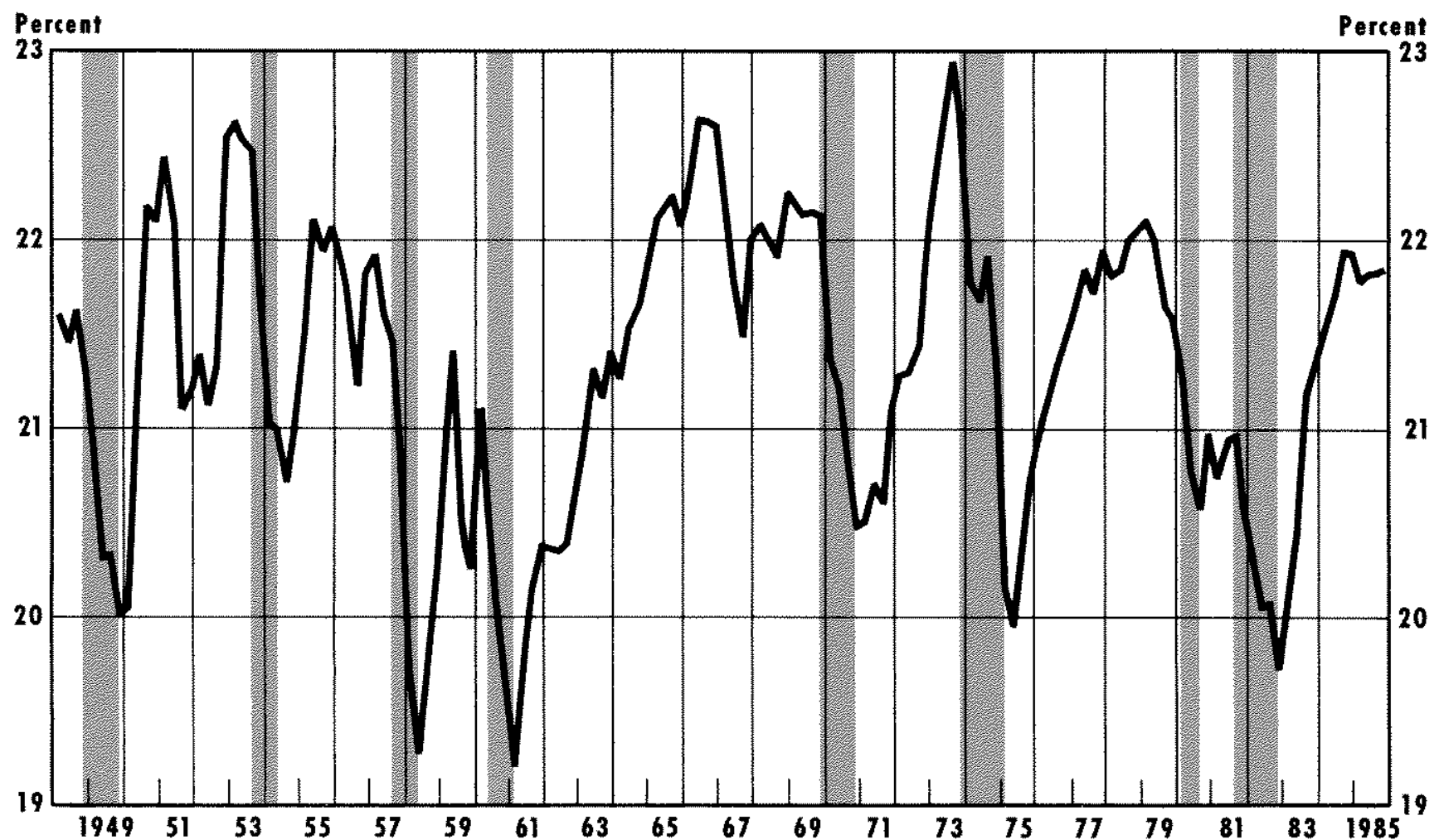

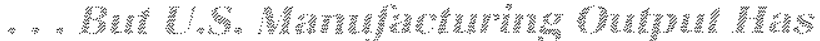

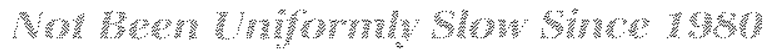

While manufacturing output growth has had periods of weakness in the 1980s, it has not been uniformly slow. From III/1980 to I/1985, the period of strong appreciation, manufacturing output rose at a 4 percent rate. Such growth is hardly weak compared with the earlier record for such growth. More important, to the extent that the dollar appreciation explains the 1984-85 weakness in manufacturing, the effect was mysteriously late.

As chart 4 shows, the share of manufactured output in real GNP since 1948 is strongly cyclical." From 1980

5tonas (1986) discusses the unchanged share of manufacturing output in real GNP but argues that a declining share of nominal spending on manufactured products is more relevant. He cites a Congressional Budget Office view that supports this. But, of course, the declining share of nominal spending reflects the difference in these two measures, the continuing tistotical decline in the price of U.S. manufactured products relative to output pices generally. The latter is correctly regarded to be a sign of the strength of the growth of productivity and output in this sector. to 1982 , when real income growth declined, this share fell sharply. From 1982 to 1984, when real income grew rapidly, it rose. The recent slow growth in manufacturing output, which appears to be concentrated in 198485 and earlier in 1980-82, is not surprising in light of the relatively slow growth in real GNP over the same periods. Moreover, the share of manufacturing output in real GNP has remained steady recently and does not appear low relative to the previous experience?

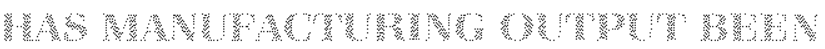 by

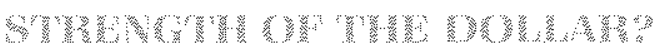

The casual evidence above indicates that the answer to this question is no. The question can also be

7From $1 / 1948$ to $11 / 1980$, the average level of the share of manufacturing output in real GNP was 21.4 percent, while the average level of the Federal Reserve index of capacity utilization, a measure of the cycle, was 82.8 percent. Over the period III/1984 to IV/1985, the utilization rate was somewhat lower, averaging 80.6 percent, but the share of manufacturing output was higher, averaging 21.9 percent. 
addressed by comparing manufacturing output growth in the 1980s with that from 1976 to 1980 when the dollar was falling. From III/1980 to $1 / 1985$, manufacturing output grew at a 4,0 percent rate; this was the 18-quarter period over which the exchange rate of the dollar rose by 83 percent. Over the preceding 17 quarters (IL/1976 to III/1980), the exchange rate fell by about 20 percent, but manufacturing output grew at only a 2.0 percent rate. The growth of manufacturing output was stronger during the recent period of dollar appreciation than it had been over the previous period of dollar depreciation. If there is a relationship between changes in the value of the dollar and in manufacturing output, it appears to be a positive one, not the negative one cited by recent analyses.

A more rigorous test should take into account the strongly cyclical behavior of manufacturing output growth. After all, in the earlier period, the capacity utilization rate was little changed at 77.0 percent (II/1976) and 77.1 percent (II/1980), while in the more recent period it rose slightly to 80.5 percent (//1985) Such a cyclical improvement could be expected to rase manufacturing output growth in the recent period relative to the earlier period.

To assess the exchange rate hypothesis, the relationship between manufacturing output growth and real GNP was first established for the period from III/1947 to IEL/1980. This relationship is:

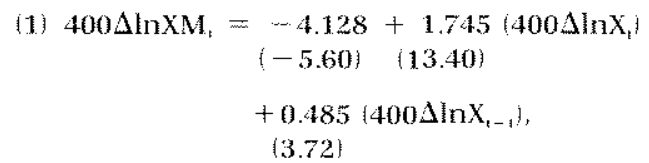

where $X_{1}$ is manufacturing output and $X_{\text {, is real }} \mathrm{GNP}$ in quarter $t$; growth rates are measured as 400 times the difference in the logarithm of the output series, which provides continuously compounded growth rates. The standard error (SE), $\overline{\mathbf{R}}^{3}$ and Durbin-Watson

\footnotetext{
${ }^{8} A$ search of the lagged relationship between $X M$ and $X$ up to tour past quarters was conducted. Only one past value is significant for real GNP. Virtually the same results are obtained using quarterly industrial production growth on the left-hand-side of equations 1 and 2. The fact that $X M$ is a component of $X$ cannot influence the results here. To verify this, the results in this section were examined using compounded annual rates of change and decomposing reat income growth into the lagged share of manufacturing output in real GNP times the growth rate of manufacturing output and a corresponding product for nonmanufacturing output. This allows the removal of the cutrent period's manufacturing output growth from the right-handside of equation 1 . The hypothesis that the effect of weighted past growth in manufacturing or nonmanufacturing output is the same could not be rejected and none of the results reported here were affected
}

Table 1

Actual and Predicted Manufacturing Output Growth

\begin{tabular}{|c|c|c|c|}
\hline & Actual & Predicted & Error \\
\hline W1980 & $137 \%$ & $48 \%$ & $89 \%$ \\
\hline 11981 & 31 & 117 & 80 \\
\hline 11 & 27 & 28 & 54 \\
\hline 11 & 26 & ग1 & 43 \\
\hline $\mathrm{V}$ & 146 & 131 & 15 \\
\hline 11982 & 99 & 175 & 76 \\
\hline 1 & -48 & $\$ 50$ & 02 \\
\hline II & -24 & 901 & 67 \\
\hline $\mathrm{W}$ & 65 & 4.6 & 19 \\
\hline 11983 & 122 & 30 & 92 \\
\hline 11 & 146 & 127 & 19 \\
\hline 11 & 189 & 73 & 116 \\
\hline 10 & 98 & 113 & 144 \\
\hline 11984 & 149 & 185 & 37 \\
\hline 11 & 76 & 98 & 222 \\
\hline III & 71 & 18 & 53 \\
\hline Y & 00 & 21 & 21 \\
\hline 11985 & 10 & 25 & 115 \\
\hline 1 & 20 & 05 & 25 \\
\hline 11 & 30 & 16 & 14 \\
\hline $\mathrm{V}$ & 13 & 14 & 27 \\
\hline Mean & 3.6 & 16 & 20 \\
\hline Mea & rrors 5 & & \\
\hline
\end{tabular}

NOTE Results are based on the II/ 1947 III/1980 telationship in equation 1 in the text Entries do not add due to rounding.

(DW) statistics are also given; t-statistics ate in parentheses.

Equation 1 has two fundamental properties. First, when real GNP growth equals its average growth rate of 3.4 percent, virtually the same growth rate of manufacturing output is observed; from 1947-80, the share of manufacturing output has shown no trend ichart 4 . Second, manufacturing output growth is strongly cyclical, with each 1 percent faster or slower growth in real income associated with over twice (2.23) as large at deviation in the growth rate of manufacturing output.

When the equation is used to simulate the growth rate of manufacturing output in 1980-85, the predicted values are those shown in table 1 . The root ${ }^{-}$ mean-squared error is a measure of the range of forecast error; it is smaller than the standard error of the equation over the earlier period. The mean errot over the period is positive, indicating that, on average, the growth of manulacturing output was stronger over the 
past five years than the prior cyclical relationship would predict. Over the recent period of weak manufacturing growth, IfI/1984-IV/1985, when it averaged only a 1.5 percent rate, the predicted growth rate based on real GNP growth alone was about zero. Thus, even over this period, manufacturing output was relatively stiong."

To test the exchange rate hypothesis, the growth rate of the exchange value of the dollar $\left(400 \Delta \mathrm{nn} \mathrm{EX}_{\mathrm{i}}\right)$ was added to the equation. The exchange rate hypothesis indicates that, given GNP growth, an appreciation of the dollar should weaken manufacturing output growth; the coefficient should be negative."

When the full period from IIJ/1947 to IV/1985 is used, the results are significantly counter to the exchange rate hypothesis. The estimate is:

$$
\begin{aligned}
(2) 400 \Delta \ln X M= & -2.95+1.52\left(400 \Delta \ln X_{1}\right) \\
& (-3.95)(10.95) \\
& +0.59\left(400 \Delta \ln X_{1-4}\right)+0.095\left(400 \Delta \ln \mathrm{EX}_{4-3}\right) . \\
& (4.22) \quad(2.00)
\end{aligned}
$$

Only the exchange rate three quarters earlier exhibits any significant relationship with manufacturing out put, so other lags have been omitted. Equation 2 indicates that there is a positive, not a negative, relationship between the exchange value of the dollar and manufacturing output." Thus, the strength of the ex-

'Solomon (1985) and Lawrence have noted the strength of U.S. industrial production growth in the early 1980 s, based on the annual relationship of such growth to the growth rate of real GNP from 1951 to 1981 .

A search of up to four lags of the exchange rate movement was conducted. The same test was done using the reat exchange rate, but the results are nearly identical since movements in the nominal and real exchange rate have been about the same.

"IIt is conceivable that a rise in the exchange rate has its dominant impact on real income, and that manufacturing adjusts in line with equation 1 . But such a result is at odds with the notion that exchange rate movements have a disproportionate effect on manufacturing. beyond those associated with any induced cyclical movements in U.S. real income. This possibility is also at odds with the paucity of evidence suppoting the hypothesis that exchange rate movernents affect reat GNP. The ambiguity of the evidence on this issue has been noted by Anderson (1985). A simple test of the hypothesis is to regress the growth rate of real GNP on current and past changes in the exchange rate and a constant over the period when the exchange rate changes, $1 / 1967-1 / / 1985$. There are no significant exchange rate effects in such an investigation for up to four lagged values of exchange rate movements, even when they are entered separately or in groups of up to five terms.

${ }^{12}$ The positive relationship between U.S. manufacturing output and the exchange rate is not a recent development. For the $1947-30$ period, the estimate in equation 2 is virtually the same as that shown for the longer period, and the exchange rate coefficient and lag change rate over the past fve years has been associated with a significant boost in manufacturing output growth $^{z 3}$ Apparently, the appreciation of the dollar has been associated with economic developments that were expected to raise U.S. productivity. While equation 2 refutes the exchange rate hypothesis, the positive relationship between the exchange rate and manufacturing output warants more explanation.

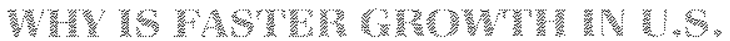

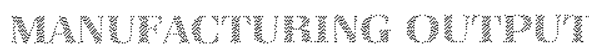

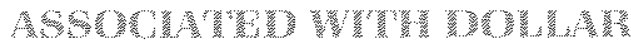

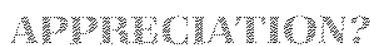

The exchange rate hypothesis is based on the link between the exchange rate and relative demands for products. But, over the past five years, the exchange rate has moved opposite to that expected based on demand conditions in goods markets alone.

The exchange rate, like any price, is determined by supply and demand. focusing initially only on the use of the dollar to facilitate intemational goods transactions, the demand for a flow of dollars in international exchange depends on the dollar value of foreign demand for $\mathrm{U} . S$. goods. Given other factors that influence this demand, the quantity demanded varies inversely with the value of the dollar. When the foreign currency price of the dollar rises, U.S. goods become more expensive to foreigners and they reduce their pur" chases; thus, the quantity of dollars demanded to pay for our exports falls.

Similarly, a rise in the exchange value of the dollar reduces the dollar prices of goods imported from abroad. This prompts residents to buy more foreign goods or inchease imports. Thus, the quantity of dollars supplied to pay for increased U.S. imports would rise with the exchange rate." Lquilibrium occurs

structure is the same and similary significant. Tests of whether the coefficients in equations 1 or 2 changed after exchange rates begar to move more freely in $1 / \$ 973$ indicated that there were no such changes. Of course, other factors, such as protectionist changes in U.S. trade policy like voluntary export restraint agreements on Japarese autos, may have contributed to the recent strength of U.S. manufacturing, but in the aggregate data, this is not apparent.

13An in-sample experiment using equation 1 shows the other side of this relationstip. Most of the previous decline in the trade-weighted value of the dottar occurred from $1 / 1976$ to $11 / 1978$. During this period, U.S. real income experienced a strong cyclical recovery, rising at a continuous rate of 4.9 percent. Using equation $t$, the predicted orowth rate in manufacturing output is 11 percent, but such growth was only 6.9 percent over the period.

${ }^{4}$ This requires that the increased volume of purchases more than offsets the decline in the dollar price of imported foreign goods. 


\section{Table 2}

\section{The Shrinking Share of International Transactions in U.S. Economic Activity}

\begin{tabular}{|c|c|c|c|c|}
\hline & \multicolumn{2}{|c|}{1980} & \multicolumn{2}{|c|}{$1 \mathrm{~A} / 1984-1 / 1985$} \\
\hline & $\begin{array}{l}\text { Billions } \\
\text { of dollars }\end{array}$ & $\begin{array}{l}\text { Percent of } \\
\text { U.S. GNP }\end{array}$ & $\begin{array}{l}\text { Billions } \\
\text { of dollars }\end{array}$ & $\begin{array}{l}\text { Percent of } \\
\text { U.S. GNP }\end{array}$ \\
\hline Net foreign investment in the United States & $\$-28.0$ & $-1.0 \%$ & $\$ 77.0$ & $2.0 \%$ \\
\hline Foreign investment & 58.1 & 2.1 & 76.5 & 20 \\
\hline U.S. investment abroad & 86.1 & 3.2 & -0.5 & 0.0 \\
\hline
\end{tabular}

where the supply and demand for dollars in the foreign exchange market are equal at some level of the exchange rate.

The dollar rises in value only if the demand for dollars rises or the supply of dollars falls. But these shifts correspond to a rise in exports of a fall in U.S. imports. Since 1980, however, real exports generally have falken while real imports have risen. Thus, movements in relative demands for U.S. goods appear to have little to do with exchange rate developments since 1980 .

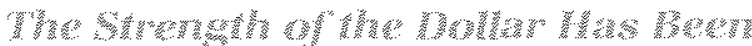 A.

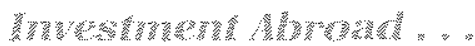

The demand for U.S. and foreign goods and corres" ponding demand and supply of dollass in foreign exchange markets are inadequate explanations of recent developments. More than goods and services are traded among nations. U.S. residents also acquire real and financial assets abroad, supplying dollars in international exchange; likewise, foreignes's acquire U.S. real and financial assets, demanding dollars in international exchange markets to facilitate the exchange.

When there is a shift in the demand and/or supply of dollars due to such investment flows, the exchange rate can also change. Thus, a rise in the value of the dollar in international exchange can occur either be cause of an increase in foreign investment in the United States or because of a teduction in U.S. investment abroad. Most analyses of foreign exchange developments emphasize the fomer ${ }^{4 .}$ The latter, however,

i5 For example, see Morgan Guaranty Trust Company (1985): "It is generally accepted that the rise in the dollar in recent years was has been the dominant force in the $1980 \mathrm{~s} .{ }^{\text {fs }}$

Table 2 shows the swing from net U.S. investment abroad to a net capital inflow. But this swing was not due to growth in foreign investment in the United States.7 Instead, the pace of U.S. investment abroad slowed to a halt (a negative $\$ 0.5$ billion). The rise in the dollar from 1980 to 1985 primarily was associated with a decline in the U.S. supply of dollars in international exchange for foreign assets. ${ }^{\text {is }}$

\section{*

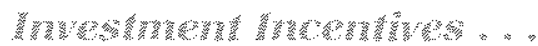

Two major intermational factors were the proximate causes of these foreign exchange market developments and the relative strength of U.S. mamufacturing. First, the 1981 tax act substantially improved the fate of return on investment in the United States. This set in motion a major reallocation in the world capital stock toward U.S. production and away from foreign production. Economic capacity began rising in the

primarily the result of an unusually large demand for dollars from foreigners wishing to buy dollar denominated assets."

16Net foreign investment in the United States generally rose throughout the period ll/1980 to $1 / 1985$, but during the first two years, both U.S investment abroad and foreign investment in the United States increased, especially in 1982

${ }^{17}$ While foreign investment in the United States did not keep pace with the growth in U.S. GNP, it did represent a major increase in such outtays viewed from the toreign perspective. Recall that each dollar of such investment had a foreign currency cost that was about 70 percent more in the year ending in $1 / 1 / 1985$ than it did in 1980 . Viewed from the foreign currency perspective, even an unchanged dollar investment level would have been impressive.

19 The other component of the suppy of doltars in international ex change - U.S. import spending - asso fell telative to U.S. GNP over the period. An 1980 , imports equaled 11.7 percent of GNP; this declined to 11.4 percent of GNP in the year ending in $\mathrm{W} / 1985$ 


\section{Table 3}

\section{The Annual Growth Rates of Real GNP Across Countries}

\begin{tabular}{|c|c|c|c|}
\hline & $1980-84$ & $1976-80$ & Change \\
\hline United States & $2.7 \%$ & $3.2 \%$ & $-0.5 \%$ \\
\hline Canada & 1.7 & 2.4 & -0.7 \\
\hline Japan & 3.8 & 5.0 & -1.2 \\
\hline Belgium & 0.5 & 1.9 & -1.4 \\
\hline Denmark* & 2.0 & 1.5 & 0.5 \\
\hline France $^{*}$ & 1.1 & 2.8 & -1.7 \\
\hline Germany & 0.8 & 2.8 & -2.0 \\
\hline Italy" & 0.4 & 3.3 & -2.9 \\
\hline Netherlands: & 0.0 & 3.3 & -3.3 \\
\hline Noway & 22 & 4.4 & -22 \\
\hline Sweden ${ }^{*}$ & 1.5 & 1.2 & 0.3 \\
\hline United Kingdom" & 1.3 & 1.2 & 0.1 \\
\hline
\end{tabular}

*Real gross domestic product where indicated.

United States relatwe to that in the rest of the world." Second, in addition to the reduction of output growth abroad due to a telative capacity loss, cyclical forces convibuted to a loss in output and income growth abroad $A$ a result, foreign demand and consumption of goods exported and imported by the United States fell relative to U.S. domestic demand, depessing world prices of traded goods.

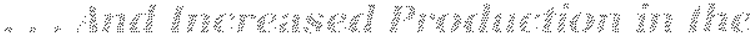

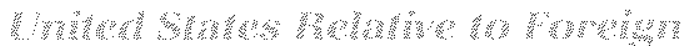

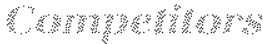

Table 3 shows the growth rates of real GNP in 12 countries during the period of dolar depreciation. 1976-80, and during 1980-84, when the dollar appreci-

\footnotetext{
19The decline in the cost of capital resative to that abroad was not the only factor accounting for difterential capacity growth. See below. There is considerable disagreement among analysts conceming the effects of taxes on the cosi of capital and investment. Many argue that 1982 tax changes repealed the 1981 investmen incentives. Bosworth (1985) and Slemrod (1986) present the view that invest ment was not boosted by tax law changes. Meyer (1984) argues that the net cost of capital was lowered on average. He also notes areas where it was raised. Two of the strongest areas of investment business automobiles and commercial and industrial bulidings, are areas where Meyer shows the lazgest reduction in the net cost of capital. Also, see Tatom (1985).

20The monetary approach to the balance of payments emphasizes relative money stock and real income growth. See Kemp (1975), for example. He shows that, in the monetary approach, an appreciation of the exchange rate occurs when domestic money stock growth slows, or when domestic real income growth accelerates relative to that in the resi of the world.
}

ated. In the earlier period, U.S. real GNP growth was exceeded in Japan, Norway, Italy and the Netherlands. Over the later period, all of the countries except fapan showed slower growth than the United States. More important, the growth rate slowed in $1980-84$ relatively more than in the United States in every country but the United Kingdom, Denmak and Sweden, where real output growth was sluggish in both periods.

Unemployment developments show the same relatively poor performance in other countries. The area encompassing the European members of the Organization for Economic Cooperation and Development (26 countries) showed an increase in unemplowment from 6.1 percent of the labor force in 1980 to 10.7 percent in 1984. Over the earlier period unemployment rose less, up from 5.4 percent in 1976. In Canada, the unemployment ate nose from 7.1 percent in 1976 to 7.4 percent in 1980 , then to 11.3 percent in 1984 . In Japan, the unemployment rate was the same in 1980 as in 1976 , at 2 percent of the labor force, then rose to 2.7 percent in 1984. In contrast, the unemployment rate in the United States fell from 7.6 percent in 1976 to 7.0 percent in 1980 . From 1980 to 1984 , the rate rose 0.5 percentage points, a smaller increase than in the 26 countries of OECD-Europe, Canada of Japan."

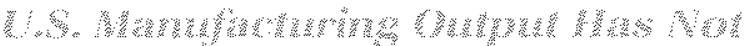

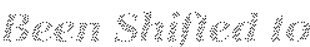

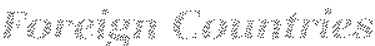

Another way to see whether foreign exchange devel opments have weakened U.S. manufacturing is to examine trends in manufacturing in other countries from 1976 to 1980 , when the exchange value of the dolar generally fell, and from 1980 to 1984 , when it rose. According to the exchange rate argument, if $U . S$. production was weakened by the rise in the exchange rate, foreign mations would be expected to have had stronger manufacturing output growth due to ther falling exchange rate.

As table 4 shows, the growth rate of US. manufacturing output from 1980 to 1984 was second only to that

\footnotetext{
2t The dominance of the improvement in the relative growth of the U.S. economy in accounting for the rise in the value in the dollar is reinforced by the fact that between $1976-80$ and $1980-85$, the growth rate of $M 1$ accelerated in the United States, but slowed in al the other countries shown in table 3 . Such monetary trends would be expected to lower the value of the dallar against these other currencates.

${ }_{22}^{2}$ The latest year for which the data used is available for all the countries examined is 1984 . The data on manufacturing in table 4 and table 5 below are Bureau of Labor Statistics meastres de scribed by Dean, Boissevain, and Thomas (1986).
} 
Table 4

Annual Growth Rates of Manufacturing Output and the Effective Exchange Rate

\begin{tabular}{|c|c|c|c|c|c|c|}
\hline & \multicolumn{3}{|c|}{ Manufacturing Output Growth } & \multicolumn{3}{|c|}{ Effective Exchange Rate } \\
\hline & $1980-84$ & $1976-80$ & Change & $1980-84$ & $1976-80$ & Change \\
\hline United States & $3.4 \%$ & $2.6 \%$ & $0.8 \%$ & $9.5 \%$ & $-.2 .8 \%$ & $12.3 \%$ \\
\hline Canada & 0.6 & 2.4 & -1.8 & 1.5 & -5.5 & 7.0 \\
\hline Japan & 7.4 & 7.0 & 0.4 & 5.5 & 5.0 & 0.5 \\
\hline Belgium & 1.3 & 1.9 & -0.6 & -6.0 & 3.0 & -9.0 \\
\hline Denmark & 1.8 & 3.1 & -1.3 & -5.7 & -0.9 & -4.8 \\
\hline France & 0.7 & 2.6 & -1.9 & -8.6 & -0.3 & -8.3 \\
\hline Germany & 0.2 & 2.1 & -1.9 & -1.0 & 5.3 & -6.3 \\
\hline Italy & -0.5 & 4.2 & -4.7 & -8.2 & -5.0 & -3.2 \\
\hline Netherlands & 1.0 & 1.9 & -0.9 & 1.3 & 4.0 & -5.3 \\
\hline Norway & 0.0 & 0.0 & 0.0 & -3.9 & -0.5 & -3.4 \\
\hline Sweden & 2.0 & -0.5 & 2.5 & -7.7 & -2.1 & -5.6 \\
\hline United Kingdom & 0.2 & -1.7 & 1.9 & -4.9 & 2.9 & -7.8 \\
\hline
\end{tabular}

in Japan. Moreover, such growth rose by more than in any nation shown except sweden and the United Kingdom. If the trends in each county in table 4 are influenced by exchange developments, then each country's exchange rate index against all other currencies would be important. ${ }^{2}$ From 1980 to 1984, the effective exchange rate of each country's curvency in table 4 fell, and fell faster than from 1976 to 1980 , except in the United States, Canada and Japan. In Japan and Canada like the United States, the currency apprectated in $1980-84$ relative to its change in $1976-$ 80.

Only Canada, Sweden and the United Kingdom show a negative relationship between changes in the value of the country's currency and the growth rate of its manufacturing sector. The evidence is not intended to show that an appreciating currency is always associated with relatively strong manufacturing growth, since such a conclusion is as questionable as

\footnotetext{
23it might be objected that the countries examined in the table are no representative of the areas where trade and production have shiffed. An the first half of 1985, however, Europe, Canada and Japan accounted for 63 . of U.S. imports and 59.8 percent of U.S. expons, up from 50.4 percent and 56.4 percent, respectivey, in 1980. The rise in the shares more than of set a decline in these countries' importance in U.S. trade from 1975 to 1980. Another indicator is that world exports (including or excluding the United States) declined from 1980 to 1984 , following nearly 20 percent annual growth in the earlier period.

The effective exchange rate is a weighted average of the value of a country's currency relative to other currencies. It is constructed by the International Monetary Fund and described in more detail in their International Monefary Statistics Yearbook (1985), pp. 6-7.
}

the contrary view. But this has been the case for nine of 12 countries in the 1980 s, and there is little evidence that U.S. manufacturing output was weakened or that it lost out to foreigrn competitors.

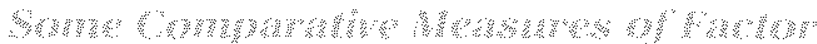

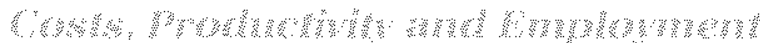

A key part of the international explanation of manufacturing output growth in the United States is that the competitive position of this sector worsened due to foreign competition and the strength of the dollar. A look at the data on factor costs and productivity, however, does not reveal a detelioration in U.S. competitiveness.

Try available to business following the 198 tax act led to an increase in domestic investment demand. course, relatively stronger investment increases financing demands, raising the real rate of retum on financial instruments including stocks, bonds and short term debt. But foregn producers did not gain from accelented cost recovery, lower corporate income tax ates or the extension of the investment tax credit in the United States. Instead, they simply had to adjust to the higher real mates of return required on financial instruments and real atssets in the world capital market. Thus, the international competitiveness of 0,5 , industry generally improved.

\footnotetext{
${ }_{25}^{25}$ The strength of U.S. domestic saving and investment is discussed in Tatom (1985).
} 
Table 5

Growth Rates of Manufacturing Unit Labor Cost, Productivity and Real Wages

\begin{tabular}{|c|c|c|c|c|c|c|}
\hline & \multicolumn{3}{|c|}{ Unit labor cost growth } & \multicolumn{3}{|c|}{ Productivity growth } \\
\hline & $1980-84$ & $1976-80$ & Change & $1980-84$ & $1976-80$ & Change \\
\hline United States & $2.3 \%$ & $8.3 \%$ & $-6.0 \%$ & $4.0 \%$ & $1.1 \%$ & $2.9 \%$ \\
\hline Canada & 6.2 & 8.2 & $-2,0$ & 2.3 & 1.4 & 0.9 \\
\hline Japan & -0.8 & 0.6 & -1.4 & 5.5 & 6.8 & -1.3 \\
\hline Beigium & 1.8 & 3.7 & $\cdots .9$ & 5.7 & 5.9 & -0.2 \\
\hline Denmark & 6.5 & 6.5 & 0.0 & 1.3 & 3.9 & -2.6 \\
\hline France & 8.0 & 8.9 & -0.9 & 5.0 & 4.2 & 0.8 \\
\hline Germany & 1.7 & 5.1 & -3.4 & 3.6 & 2.9 & 0.7 \\
\hline taly & 13.5 & 12.6 & 0.9 & 3.6 & 4.3 & -0.7 \\
\hline Netherlands & 0.3 & 3.1 & -2.8 & 5.2 & 4.4 & 0.8 \\
\hline Norway & 6.9 & 7.0 & -0.1 & 2.7 & 2.3 & 0.4 \\
\hline Sweden & 4.9 & 7.1 & -2.2 & 4.1 & 2.6 & 1.5 \\
\hline \multirow[t]{3}{*}{ United Kingdom } & 3.5 & 16.4 & -12.9 & 5.7 & 0.1 & 5.6 \\
\hline & \multicolumn{3}{|c|}{ Real wage growth } & \multicolumn{3}{|c|}{ Manufacturing employment growth } \\
\hline & $1980-84$ & $1976-80$ & Change & $1980-84$ & $1976-80$ & Change \\
\hline United States & $0.3 \%$ & $0.2 \%$ & $0.5 \%$ & $-1.0 \%$ & $1.7 \%$ & $-2.7 \%$ \\
\hline Canada & 0.3 & 0.7 & -0.4 & -1.4 & 1.1 & -2.5 \\
\hline Japan & 1.7 & 1.4 & 0.3 & 1.5 & -0.3 & 1.8 \\
\hline Belgium & 0.1 & 4.0 & -3.9 & -3.2 & -3.3 & 0.1 \\
\hline Denmark & -0.8 & 0.0 & -0.8 & 0.2 & -0.5 & 0.7 \\
\hline France & 2.6 & 2.5 & 0.1 & -2.5 & -1.1 & -1.4 \\
\hline Germany & 1.0 & 4.3 & -3.3 & -2.8 & 0.3 & -2.5 \\
\hline ftaly & 2.2 & 0.3 & 1.9 & -28 & -0.1 & -2.7 \\
\hline Netheriands & 0.8 & 2.2 & --1.4 & -36 & -1.8 & -1.8 \\
\hline Norway & 0.1 & 1.2 & -1.3 & -2.8 & -0.8 & -2.0 \\
\hline Sweden & -0.5 & -0.2 & -0.3 & -2.4 & -1.5 & 0.9 \\
\hline United Kingdom & 1.8 & 2.1 & -0.3 & -.5 .6 & -1.2 & -4.4 \\
\hline
\end{tabular}

th the the Another key factor influencing comparative costs is the cost of labor per unil of ouput. Table 5 compares manufacturing unil labor cost across countries. In the first column, the rate of increase in unit labor cost is shown for the period of dollar appreciation from 1980 to 1984 . The rate of increase in unit labor cost is not the slowest in the United Slates, though it is well below the rate in many of the counties shown.

In the second and third columns, the rate of increase in unit labor cost over the period of dollat depreciation, $1976-80$, and the differences between the two periods are showt. In the 1976-80 period, the pace of unit labor cost increase in the United States was among the highest shown. There is a wide gap between the slowing in the United States and that in the other 10 countries shown. Thus, frends in unit labor cost suggest that the competiveness of U.S. manufacturing improved over the recent four years.

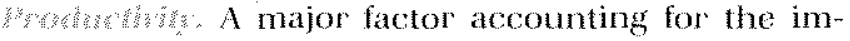
provement in unit labor cost is a relative improvement in productivity growth in manufacturing. While U.S. manulacluring productivity growth from 1980 to 1984 was about average compared with the other countriss, it improved sharply from the $1976-80$ period, when it was much lower than in 10 of the other 11 countries shown in table 5 .

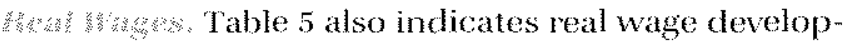
ments over the two periods ${ }^{2 t}$ Real wage movenents reflect changes in supply and demand. Thus, a rise in real wages can occur due to eilher a increase in the

\footnotetext{
${ }^{26}$ Real wage growth in each country is measured by the rate of increase in houly compensation in manufacturing deflated by the consumer price index in each country. Similar results are found deflating by the price indexes for manufacturing or industrial prices published by the IMF.
} 
demand for labor or a rise in the supply price of labor: or some combination thereof. In the former case, employment tends to rise, while in the latter case employment tends to fall. Thus, evidence on real wages alone does not indicate whether demand, supply or both are changing.

The implication of the international explanation, however, is that, by shifting the demand for manufacturing output away from the United States toward foreign competitors, the demand tor labor abroad would rise and that in the United States would fall. As a result, real wages in the United states would tend to decline relative to those in other countries. Real wage growth in the United States was higher in 1980-84 than it was in the earlier period, however. This improvement was larger in the United States than in all the other countries except Italy. Indeed, in eight of the other nations real wage growth fell between the two periods.

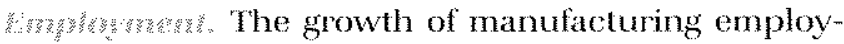
ment in the 12 countries is shown at the end of table 5 . It, 100 is at odds with the view that manufacturing output and employment are being redistributed away from the United States. While the table indicates that U.S. manufacturing employment declined from 1980 to 1984 , the decline compares favorably to developments in the other 11 countries. Only lapan and Denmark showed an increase in employment over the 1980-84 period ${ }^{x}$

The decline in employment growth in the United States over the two periods is among the largest in the table. As table 4 indicates, however, this decline was not due to reduced output growth. Instead, the dedine reflects the relatively strong pace of productivity growth in manufacturing over the recent period.

The use of annual rates of growth does not fully illuminate the dramatic differences that have occurred in manufacturing employment across the countries. Over the full period in table 5 , only Japan and the United States showed growth in manufacturing employment, but it was up less than 5 percent in each case 2.7 and 4.9 percent, respectively after eight

\footnotetext{
${ }^{27}$ Fieleke (1985) has shown that there is no correlation between the growth of import penetration in various U.S. industries and their employment growth over the 1980-84 period. Mokenzie and Smith (1986) find that textile imports in the early 1980 s and in the period 1960-84 had no significant negative effect on employment in the U.S. textle and apparel industries. They do find some evidence that apparel imports have aftected employment in the apparel industry. They find that the dominant factor influencing employment in these industries has been relatively rapid productivity growth in both industries.
}

years. In Canada and Denmark, such employment fell about 1 percent over the eight years. In France, Germany, Italy, Norway and Sweden, the reduction was about 9 to 15 percent. In the Netherlands, Belgium and the United Kingdom such employment fell by 201024 percent. If there is a redistribution of employment going on, it appears to be strongly in favor of the United States and Japan.

Harser. Finally, energy prices are another cost of production that has moved down in the United States compared with such prices abroad. In the Lnited States, energy prices have dechned relative to the prices of business output. This is in shap contrast to developments abroad. Since oil is a major source of energy around the world and other sources of energy compete with it, a look at the real price of oil in various countries is sufficient. Table 6 shows the 1980-84 change in the real cost of oil to domestic and foreign producers. While this price fell at a 5.2 percent rate from 1980 to 1984 in the United States, it generally rose abfoad. Only Japan shows a dectine like that in the United States. In Italy and Norway, such prices were nearly unchanged, but in the other eight countries shown, the price of oil rose shapply relative to ptices of goods and services generally.

Thus, it is difficult to argue that the international competitiveness of U.S. industry has been hurt by the rise in the value of the dollar from 1980-85. For capital and energy resources, it appears that factor prices have not isen relative to output prices in the Enited States, especially when compared with the experience of foreign competitors. For labor, it does not appear that real wages in the United States have been depressed relative to those abroad. The positive relationship between the growth of U.S. manufacturing output and the rise in the exchange value of the dollar appar. ently reflects improved competitiveness of L.S. manufacturing.

\footnotetext{
${ }_{25}^{25}$ The dollar price of imported oil in the United States is representative of the world price since oil is priced in dollars around the world and except for differences in taxes and transportation costs, the U.S. price is representative of the price for firms in other nations. The local currency price of oil is assumed to be the average cost of imported oil in the United States (dollars per barrel) multiplied by the exchange rate between the local currency and the dollar (foreign currency/dollar). For Canada, the industry seling price for petroleum and coal products is used instead of the price of imported oil The industry selling price for petroleum refineries shows the same annual rate of increase. Canada, like the U.S. in 1980, had significant regulations on domestic oil and energy prices, so that the imported price of oil is nol representative of tocal costs. In the U.S. case, the average cost of oil to domestic refiners is used to measure the dollar price of oil. These local prices of of are deflated by the consumer price index for each country to examine movements in the real cost of of in the various countries.
} 
Table 6

\section{Percentage Change in the Real Price of Oil: 1980 to 1984}

\begin{tabular}{|c|c|c|}
\hline & $\begin{array}{c}\text { Percentage } \\
\text { change }\end{array}$ & $\begin{array}{l}\text { Average } \\
\text { annual rate }\end{array}$ \\
\hline United States & $-19.1 \%$ & $-5.2 \%$ \\
\hline Canada & 26.8 & 6.1 \\
\hline Japan & -20.1 & -5.5 \\
\hline Belgium & 25.6 & 5.9 \\
\hline Denmark & 120 & 2.9 \\
\hline France & 17.8 & 4.2 \\
\hline Germany & 12.5 & 3.0 \\
\hline italy & -0.6 & -0.1 \\
\hline Netherlands & 14.5 & 3.4 \\
\hline Nonway & -3.5 & -0.9 \\
\hline Sweden & 163 & 3.8 \\
\hline United Kingdom & 112 & 27 \\
\hline
\end{tabular}

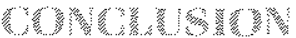

Manufacturing output in the United States does not appear to have been adversely affected by exchange rate developments since 1980 . Except for the cyclical decline associated with the 1980 and $1981-82$ recessions, manufacturing oufput has maintained its share in real GNP and has shown fairly rapid growth. Indeed, the evidence indicates that, during the $1980 \mathrm{~s}$, such output has grown 2.0 percentage points faster than the $1948-80$ relationship of such output to real income would predict. Of course, since manufacturing production rose while exports fell and imports rose, l.S. purchases of such goods rose rapidly. In effect, U.S. consumption was raised not only due to increased production, but also by purchasing U.S. products that formerly were exported and foreign products that formerly were purchased abroad.

No doubt the rise in the value of the dollat restrained the growth of aemand for U.S.-manufactured products. But the appreciation of the dollar in part simply offset improvements in the relative cost advantages of U.S. producers over foreign competitors. In industries in which these cost advantages were unusually strong or weak, the gains in production and employment were relatively stronger or weaker than the data for the whole manufacturing sector indicate. Thus, there are likely to be industries in which the rise in the exchange value of the dollar has exerted strong negative influences on production, prices and em- ployment that were not offset by relative cost improvements."

Manulacturing output growth abroad has not shown the expected gains that would occur if the exchange rate alone were reallocating world demand and production of such goods. During the period of dollar appreciation, production growth slowed sharply in most other countries. These developments reflect a redistribution of capital and output toward the United States and away from other countries. The evidence suggests that this redistribution and the ap preciation of the dollar reflect the relative cost improvements in U.S. production.

The irony, then, is that the new-found conventional wisdom, which holds that the rise in the dollat has weakened the competitive position of U.S. manufacturing, not only appears to be incorrect, but it reverses the dominant positive relationship and it obscures the recent strength of U.S. manufacturing. Adjusted for normal cyclical movements in the United States, manufacturing output has been melatively strong in the 1980 s; this is in large part related to the improvements in the competitiveness and real rate of return in U.S. manufacturing and, hence, the appreciation in the value of the dollat in the early 1980s. Nonetheless, the international explanation has led to calls for protectionist and monetary and fiscal actions to drive the exchange value of the dollar down. Such actions are likely to retard the otherwise improving competitiveness of U.S. manufacturing.

At least in the United States, exchange rate movements over the eight years from 1976 to 1984 appear to reflect policyinduced and other changes in U.S. international competitiveness. Thus, economic policies that promote low inflation and faster or more stable growth appear to be relatively more important for US. manutacturing than the exchange rate consequences of economic policy or other exchange rate developments.

\footnotetext{
${ }^{29}$ Ottput growth rates in the 10 industries in manufacturing industrial production indicate that three - transportation equipment (especially motor vehicles and parts), lumber and products, and printing and publishing - showed faster than average growth in 1980-84 and their growth rate was higher than it had been in 1976-80. The only sector where growth in $1980-84$ was below average and stower than in 1976-80 was fabricated metal products. Other industries (primary metals, apparel and products, chemicals and products, foods, electrical, and non-electrical machinery) showed mixed results on these criteria. For example, the two machinery industries showed the largest declines in 1980-84 from growth in the earlier period, but their growth exceeded the average for all 10 industries over the recent period.
} 


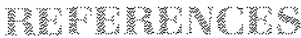

Anderson, Gerald H. "How Desirable Is Dollar Depreciation?" Federa! Reserve Bank of Cleveland Economic Commentary. Decem. ber 15,1985

Bosworth, Barry P. "Taxes and the Investment Recovery," Brookings Papers on Economic Actrity (1/1985), pp. 1-35.

Dean, Edwin, Harry Boissevain, and James Thomas. "Productivity and Labor Costs Trends in Manufacturing, 12 countries," U.S. Department of Labor, Bureau of Labor Statistics, Monthly Labor Review (March 1986), pp. 3-10.

Fieleke, Norman S. "The Foreign Trade Deficit and American Industry," New England Economic Review, Federal Reserve Bank of Boston (July/August 1985), pp. 43-52.

Friedman, Miton. A Theory of the Consumption Function (Princeton University Press, 1957).

Harberger, Arnoid C. The Demand for Durable Goods (The University of Chicago Press, 1960).

International Monetary Fund. International Financial Statistics Yearbook, 1985.

Jonas, Norman. "The Hoilow Corporation," Business Week, March 3,1986, pp. $56-59$.

Kemp, Donald S. "A Monetary View of the Balance of Payments," this Review (April 1975), pp. 14-22.
Lawrence, Robert Z. Can America Compete? (The Brookings Institution, 1984).

McKenzie, Richard B., and Steven D. Smith. "The Loss of Textie and Apparel Jobs: The Relative Importance of Imports and Productivity ${ }^{\text {"t }}$ Center for the Study of American Business, Washington University, Working Paper \#96, January 1986.

Meyer, Stephen A. "Tax Policy Effects on Investment: The 1981 and 1982 Tax Acts," Federal Reserve Bank of Philadelphia Business Review (November/December 1984), pp. 3-14.

Morgan Guaranty Trust Company of New York. "Implications of a Lower Dollar," Morgan Economic Quarterly (September 1985), pp. 8-11.

Norton, R. D. "Industrial Policy and American Renewal," Joumal of Economic Literature (March 1986), pp. 1-40.

Okun, Arthur M. Prices and Quantities: A Macroeconomic Analysis (The Brookings Institution, 1981).

Slemrod, Joel. "Taxation and Business Investment," in Phitip Cagan, ed. Essays in Contemporary Economics, 1986 (American Enterprise Institute, 1986), pp. 45-72.

Solomon, Robert. "Effects of the Strong Dollar," The U.S. Dollar Recent Developments, Outlook and Policy Options, a symposium sponsored by the Federal Reserve Bank of Kansas City, Jackson Hole, Wyoming. August 21-23, 1985, p. 65-88.

Tatom, John A. "Two Views of the Effects of Government Budget Deficits in the 1980s," this Review (October 1985), pp. 5-16. 